\title{
The role of permafrost in shaping the Late Glacial relief of northern Poland
}

\section{A.J. van Loon ${ }^{1}{ }^{*}$, M. Btaszkiewicz ${ }^{2} \&$ M. Degórski ${ }^{3}$}

1 Geological Institute, Adam Mickiewicz University, Maków Polnych 16, 61-606 Poznań, Poland.

2 Department of Environmental Resources and Geohazards, Institute of Geography and Spatial Organization, Kopernika 19, 87-100 Toruń, Poland.

3 Department of Geoecology and Climatology, Institute of Geography and Spatial Organization, Twarda 51/55, 00818-Warszawa, Poland.

* Corresponding author. Email: tvanloon@amu.edu.pl; tom.van.loon@wxs.nl

Manuscript received: July 2011, accepted: April 2012

\begin{abstract}
The presence of permafrost in Poland north of the line indicating the maximum ice extent of the Vistulian (Weichselian) glaciation after retreat of the land-ice cap has been a subject of debate for a long time. Investigations in an area at the line of the maximum ice extent of the Pomeranian phase prove that permafrost existed, indeed, after the ice retreat. This conclusion is drawn on the basis of morphological data (the presence of oriented kettle holes), sedimentological data (the nature of the infilling of the kettle holes) and pedological data (permafrost-affected horizons in soil profiles). It appears that the permafrost mostly developed in the ice-free zone that appeared after the retreat of the land-ice cap, but it is likely that some relict permafrost that had originated earlier in front of advancing ice was also still present. The landscape of northern Poland owes its relief partly to the Late Glacial permafrost.
\end{abstract}

Keywords: Permafrost, kettle holes, soil development, buried ice, morphogenesis, Late Glacial, northern Poland

\section{Introduction}

The advance of the last continental Late-Vistulian (= Late Weichselian; see Fig. 1) ice sheet divided the central European plain into two morphogenetic zones. The landscapes south of the maximum ice extent during the Last Glacial Maximum (LGM) became severely affected by the periglacial conditions (in the sense of Brodzikowski \& Van Loon, 1991, and Vandenberghe \& Thorn, 2002: the periglacial zone stretches as far in front of an ice cap as the occurrence of permafrost) that remained for a long time. This can be reconstructed on the basis of typical periglacial structures such as ice-wedge pseudomorphs and frost-cracks (cf. Vandenberghe \& Kasse, 1993a), cryopediments (Vandenberghe \& Kasse, 1993b), deflation flats, and areas covered by fluvioperiglacial sediments (Klatkowa, 1994; Van Huissteden et al., 2000; Vandenberghe, 2002). The periglacial changes are also reflected in the frost-induced imprints in soil profiles (Kowalkowski, 1990; Vandenberghe \& Czudek, 2008). On the other hand, the areas situated north of the LGM are characterised by

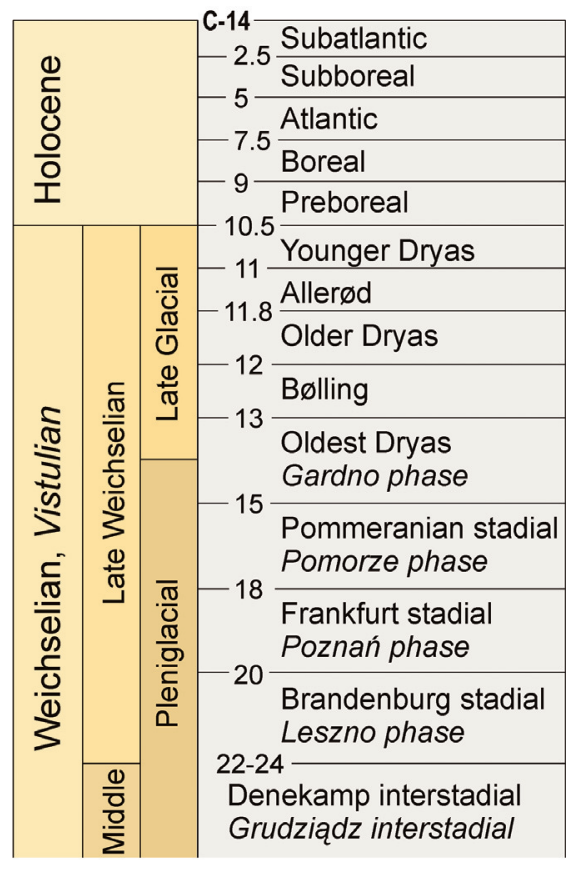

Fig. 1.

Stratigraphy of the last part of the Weichselian and the Holocene, with names used in the text. Terminology as used in western Europe in roman; Polish terminology in italics. 
a fresh post-glacial relief, and are therefore often referred to as Late or Young Glacial.

\section{Objective}

While the periglacial influence on the relief of the extraglacial areas with respect to the LGM does not give rise to any doubts, the role of periglacial conditions regarding the development of the relief North of the LGM is still a subject of debate: not only the presence of long-lived permafrost in the areas that became deglaciated during the retreat of the ice cap is still under discussion, but this holds also for the possible role of the permafrost as a factor shaping the relief. These topics became subject of a hot debate in Poland (see, among others, Kozarski, 1993; Ewertowski, 2009; Piotrowski et al., 2009) after remnants of still active permafrost were documented at a depth of $385 \mathrm{~m}$ in a borehole at Szypliszki near Suwałki, an area covered by ice during the last glaciation (Szewczyk \& Nawrocki, 2011); the implications are dealt with in the Discussion section.

In order to contribute to the just-mentioned discussion, the objective of the present study is an analysis of some geomorphological and soil characteristics; the analysis is aimed at showing whether periglacial conditions, represented by a permafrost, were present in front of the retreating Late Glacial ice cap, and - if so - how they affected areas of northern Poland morphologically.

\section{Material and methods}

Field work was carried out during the field seasons from 2009 to 2011. On the basis of literature data and earlier studies by the authors, it was decided which features might provide clues that could contribute to answer the question regarding the occurrence of permafrost. It was found that, in addition to the overall geomorphological context, the study should focus on the nature and the infilling of oriented kettle holes that occur on outwash plains. On the basis of field investigations, the kettle holes in the vicinity of Stargard Gdański have been selected for detailed investigation. The infilling of some of these kettle holes has been studied on the basis of cores from drillings, and usage has been made of palynological datings from the kettle-hole infillings.

In addition, previous studies on soils developed under periglacial conditions have indicated that both the soil development and the occurrence of specific deformation structures inside the soil profile can provide hard evidence for permafrost (e.g. Vandenberghe \& Thon, 2002). Consequently, the soil characteristics of one of the exposures dug in an outwash plain (near Stara Kiszewa) has been studied in detail to check whether features characteristic of permafrost could be found.

\section{Geomorphological setting}

Field work was carried out in the Starogard Gdański lake district and in the northern part of the Tuchola forests. This area in northern Poland was entirely covered by the Late Vistulian ice sheet (Fig. 2). A distinct marginal zone developed in the study area during the recession of the glacier, which is dated between 16,200 years ${ }^{14} \mathrm{C} \mathrm{BP}$ and 15,200 years ${ }^{14} \mathrm{C}$ BP (Marks, 2002).

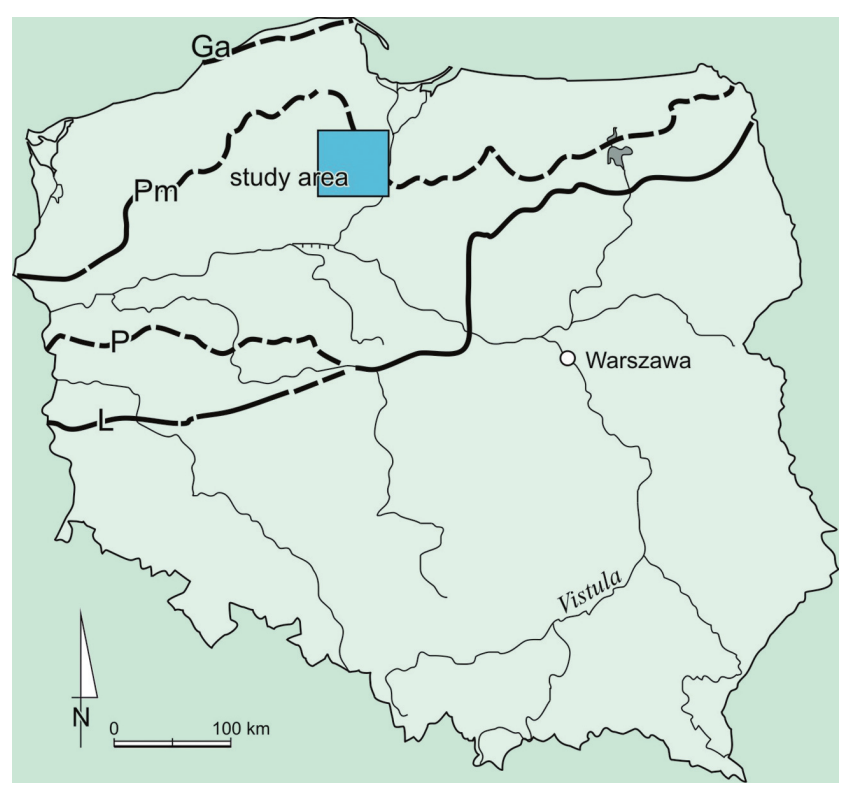

Fig. 2. Map of Poland with the location of the study area and maximum extent of the Late Vistulian ice sheet (after Kozarski, 1975). L = Leszno phase; $P=$ Poznań phase; $P m=$ Pomeranian phase; $G a=$ Gardno phase.

The dominating geomorphological elements in the study area, as far as situated in front of the maximum ice extent during the Pomeranian phase, are extensive outwash plains with numerous channels, as well as dune fields that formed during the main dune-forming phase of the Younger Dryas (Błaszkiewicz, 2005). In the hinterland of the Pomeranian phase, the moraine-covered uplands dominate; they, too, contain numerous subglacial channels that are nowadays commonly occupied by streams that jointly form polygenetic valley systems (Fig. 3).

Numerous pieces of evidence indicate the development of permafrost after the glacier had retreated. They comprise contraction cracks (see, among others, Vandenberghe et al., 2004) and other cryoturbations (Vandenberghe, 2006), frostrelated transformations of soils (Van Loon, 2009), oriented kettle-holes on the outwash plains, and long-lived conservation of earth-covered blocks of dead-ice in what now are dells. The present contribution focuses on (1) permafrost-related examples of oriented kettle holes on outwash plains; (2) changes in the soil cover related to periglacial conditions; and (3) the permafrost-favoured long-term preservation of buried ice in depressions. 

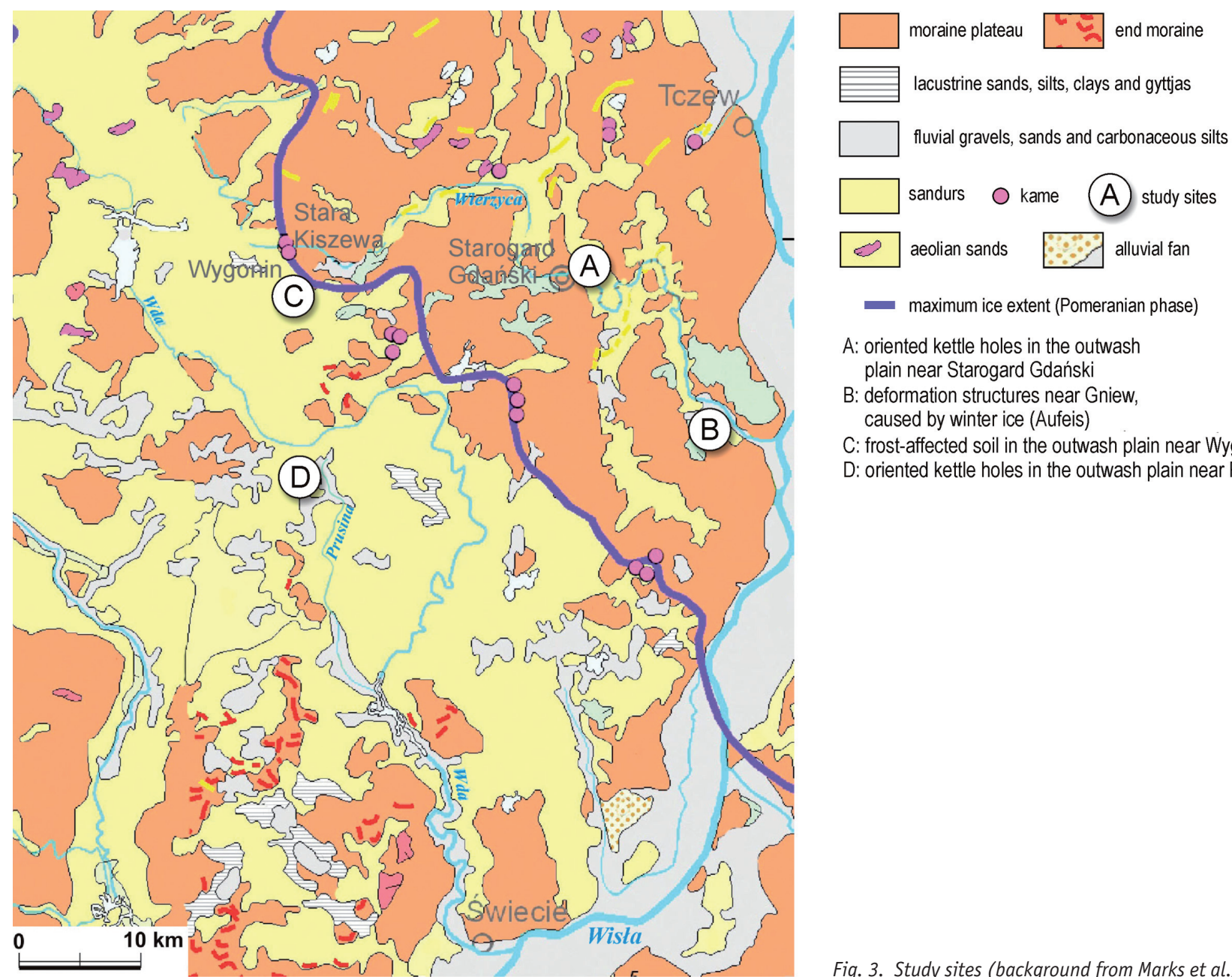

A: oriented kettle holes in the outwash plain near Starogard Gdański

B: deformation structures near Gniew, caused by winter ice (Aufeis)

C: frost-affected soil in the outwash plain near Wygonin

D: oriented kettle holes in the outwash plain near Prusina

Fig. 3. Study sites (background from Marks et al., 2006).

\section{Oriented kettle holes on outwash plains}

\section{The origin of oriented kettle holes}

Oriented kettle holes occur nowadays quite frequently on outwash plains of still glaciated areas, particulary on Spitsbergen (Cegła \& Kozarski, 1977). They form - and this is important for the reconstruction of the palaeogeographical and palaeogeomorphological situation related to 'fossil' oriented kettle holes where ice that forms on the sedimentary surface during the winter is preserved for a long time. This situation occurs if the ice masses become covered by fluvioglacial sediments (Hambrey, 1984).

The genesis of such oriented kettle holes can be summarised as follows. Meltwater forms channels in front of a land-ice cover, and meltwater runs through these channels as long as the temperature is high enough. During the winter season, the current stops, because no meltwater is supplied. At the beginning of the winter, when the water is still running, as well as at the end of the winter season, when the meltwater starts to flow again, temperature fluctuations result in occasional freezing of the meltwater water in the channels in front of the glacier, sometimes even to the bottom. This results in the accumulation of ice masses in the channels. When the spring begins and the discharge of meltwater increases significantly, the energy of the current also increases, so that a large amount of particles can be transported. As a consequence, the ice masses in the channel become covered with fluvioglacial sands and gravels (Bukowska-Jania, 2003). The sediment-covered ice masses can survive during the summer season because of the permafrost in front of the ice cover, and during the beginning (or end) of the next winter the ice masses grow again by freezing of the cold water, coming from the land-ice mass, that percolates downwards through the surficial sediments until it reaches the ice mass and then freezes. The large size of some kettle holes indicates that this process can go on for many years.

When the ice mass retreats so far that no significant amounts of very cold meltwater reach the area anymore, the buried ice masses can no longer grow in size, but they may still survive for a long time because of the permafrost that develops in front of the retreating ice cap and because the overlying fluvioglacial sediments still constitute an effective protection against melting due to higher summer temperatures at the surface. Ongoing amelioration of the climate results, however, in an increasingly thicker active layer and eventually the buried dead-ice will melt away, leaving a depression. Because the ice masses formed in a channel, these depressions tend to be oriented. 
Such 'fossil' oriented kettle holes have been identified for instance on the outwash plain of the Wda river, in the upper reaches of the Prusina river valley in northern Poland (Fig. 3). These forms are associated with a smaller subglacial channel. More oriented kettle holes are fairly common in western and middle Pomerania (Kozarski, 1975; Rachlewicz, 1991; BukowskaJania, 2003). These regions were, like northern Germany in the West (Pisarska-Jamroży \& Börner, 2011) and the Mazury Lakelands in the East (Morawski, 2009a, b), also covered by ice during the Pomeranian phase of the Vistulian glaciation (Morawski, 2009b; Gedl, 2011).

\section{Results}

The data obtained during the present study deal with two aspects: (1) the genesis and infilling of the oriented kettle holes near Starogard Gdański; and (2) the soil profile near Stara Kiszewa.

\section{Oriented kettle holes in the study area}

Oriented kettle holes on outwash plains within the study area, occur in particular in the vicinity of Starogard Gdański (the immediate hinterland of the Pomeranian phase) (Figs 3-4). They developed on the outwash plain that accumulated during the retreat of the Pomeranian-phase glacier (Błaszkiewicz, 1998). Their occurrence can, as detailed above, be explained satisfactorily only by a long-lived presence of permafrost in the outwash plain. It is noteworthy in this context that several postdepositional deformations also indicate a long-lived permafrost. These deformations are present in, for example, the sediments filling the meltwater channel in the lowermost stretch of the Wierzyca river valley (Błaszkiewicz, 1998). There occurs a network of antithetic faults in the channel sediments, but they do not pass the boundary with the floodplain sediments in which the channel is incised (Fig. 5). These deformations must be ascribed to melting of buried ice masses.

The kettle holes in the study area form characteristic semicircular, shallow basins with a maximum width of $400 \mathrm{~m}$, while narrower segments are not wider than some tens of metres (Fig. 4). They occur over a distance of almost $5 \mathrm{~km}$, following the direction of the meltwater streams. In the southern part of the study area, the lows are undercut by the edge of the Wierzyca river valley; most probably, the kettle holes originally formed a longer stretch, but this elongated depression cannot be traced anymore because of cannibalism by the Wierzyca river (Błaszkiewicz, 1998). The oriented kettle holes are well recognisable at the surface of the outwash plain by relatively gentle slopes; the mean height difference is some 2-3 m.

The morphology and the biogenic sediments (see next section) indicate that the depressions can be classified as oriented kettle holes. They constitute as a rule the lowest topographic levels of the outwash plain, representing the channels of the Late Glacial meltwater streams.
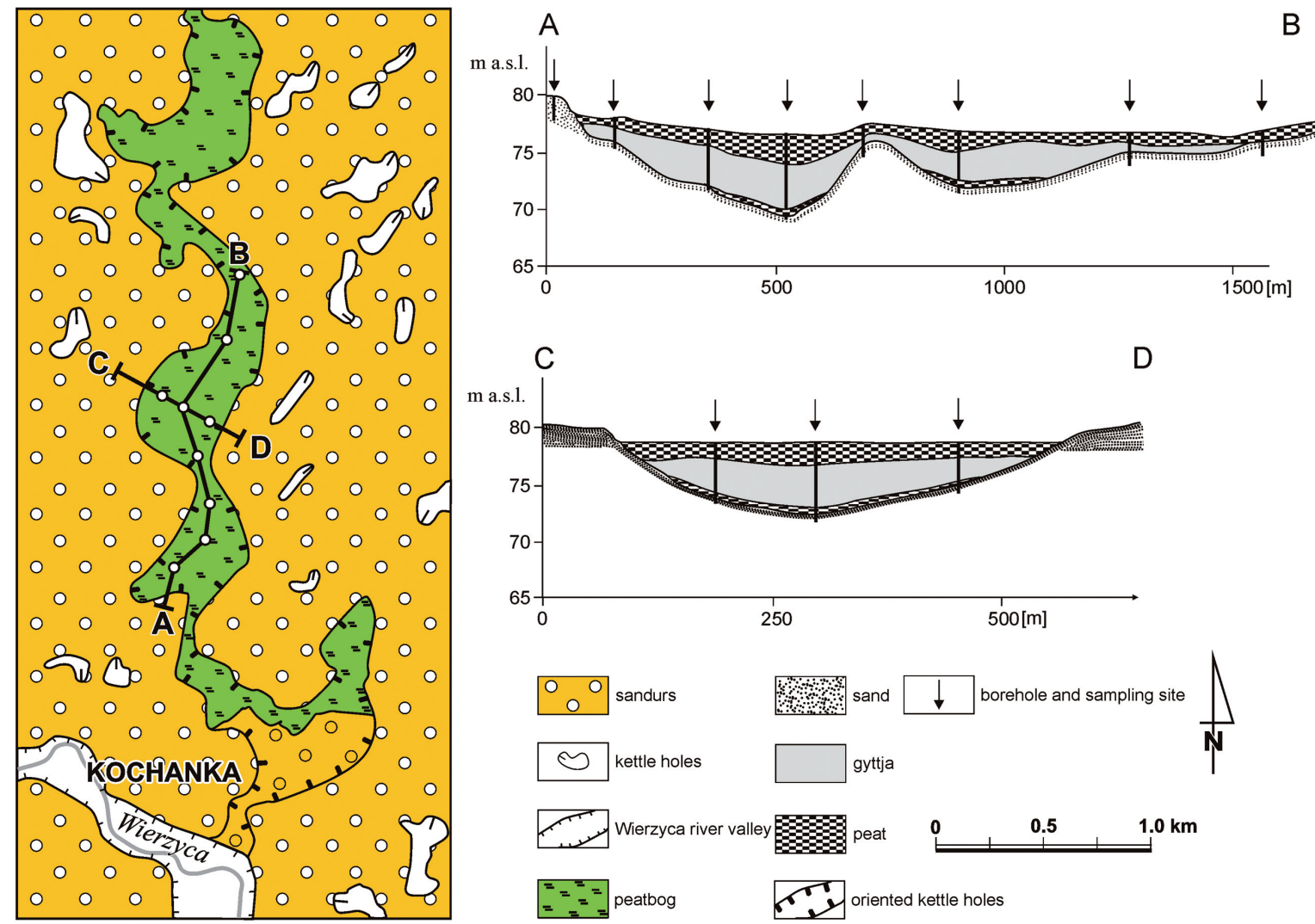

Fig. 4. Directed melt-out basins on the Kochanka-sandur near Starogard Gdański. 


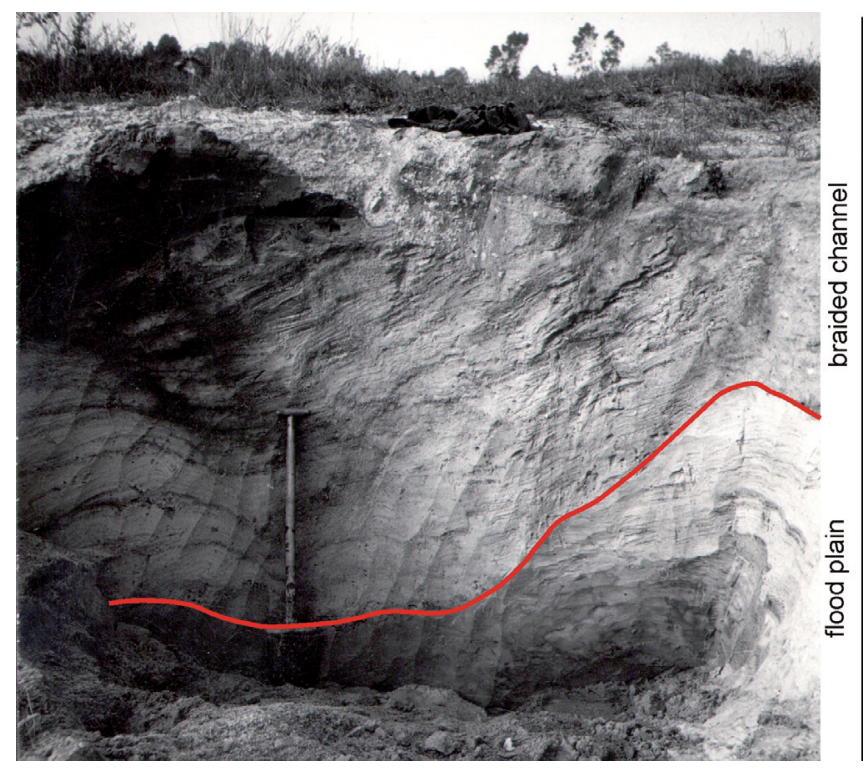

Fig. 5. Deformation structures (near Gniew) formed after winter ice (Aufeis) had built up.

\section{Infilling of the kettle holes}

Whereas the surface sediments of the outwash plain in the immediate neighbourhood of the depressions consist of fluvioglacial sands and gravels with thicknesses up to $10 \mathrm{~m}$, the deepest parts of the depressions have been infilled with organic sediments (peat and gyttja) and mineral fine-grained, mainly silty sediments that show a fine horizontal lamination (cf. Litt et al., 2001). These infillings of the deepest parts of the depressions are up to $6 \mathrm{~m}$ thick. Considering the topographical position of these sediments (in a depression) and their sedimentological context (an outwash plain with fluvioglacial deposits) we interpret these sediments as glaciolacustrine. These infillings significantly obscure the original topography of the mineral substratum of the depressions.

A basal peat layer of several centimetres thick, following the curved bottom of the depressions, has been encountered in several drillings. In all boreholes, the basal peat layers are overlain by calcareous lacustrine gyttjas, and they all rest immediately on Vistulian mineral fluvioglacial sediments (Fig. 4). The contact between the peat and the overlying gyttjas is sharp.

A first palynological analysis of the peat and the gyttjas suggests that accumulation of the peat took place during the Allerød (Noryśkiewicz, Univ. Torun, pers. comm.). The palynological dating of the lowermost biogenic infilling of the kettle holes indicates that vegetation-hostile climatic conditions remained present until the beginning of the Allerød. At the beginning of the Allerød, the active layer of the permafrost quickly started to become thicker, eventually reaching the fluvioglacial sediments. The depression that had resulted from the melting of the 'Aufeis' (ice formed at the surface by freezing of a meltwater stream during the winter, and therefore sometimes indicated with the unfortunate term 'winter ice') then turned into a swamp, resulting in the development of a tundra peat bog. The fluvioglacial sediments, overlying the still preserved ice masses, then became covered by a thin layer of (basal) peat. The ongoing paludification of the depression, resulting from the thickening of the active layer, made thermal karst possible, and water did no longer freeze to the bottom during winter. Instead, the buried ice masses started to melt away, so that a lake of some $6 \mathrm{~m}$ deep originated eventually. The layer of basal peat became covered by a thick layer of gyttja, on which, already in the Holocene, peat accumulated.

The Allerød was a phase during which the blocks of dead-ice in the majority of the depressions in northern Poland melted out (Więckowski, 1966; Niewiarowski, 2003; Błaszkiewicz, 2005). Dead-ice masses occasionally survived throughout the Late Glacial, however, until the early Holocene, for instance in the deep subglacial 'Kochanka' channel, $2 \mathrm{~km}$ west of the study area, where buried ice remained present until the beginning of the Preboreal (Błaszkiewicz, 1998).

\section{Conservation of the depressions with buried ice blocks}

The now lake-filled depressions in the Late Glacial areas of the central European lowland were not immediately filled with water after their formation (Więckowski, 1966; Niewiarowski, 2003; Błaszkiewicz, 2005). Similar time lags have also been reported for areas that had been covered by the Laurentide ice sheet (Florin \& Wright, 1969; Last \& Vance, 2002; Schwalb \& Dean, 2002). The time lag must be ascribed to the long-lived preservation of blocks of buried ice, of either glacial or nonglacial origin, thus proving unambiguously the presence of periglacial conditions after the continental ice sheet had retreated. For some depressions in northern Poland this time lag exceeded 5000 years (Błaszkiewicz, 2005, 2011).

The relationship between the duration that the buried ice in the depressions was preserved and the presence of the permafrost is well known (Nitz, 1984; Böse, 1995). Long-lived preservation of the dead-ice blocks in the absence of permafrost is difficult to imagine although - under specific conditions - feasible (Krüger \& Kjaer, 2000; Schomacker, 2008). Under permafrost conditions, buried ice blocks are preserved if the thickness of the mineral cover exceeds the thickness of the active layer (Boulton, 1967). The buried ice, in turn, determines the course of the permafrost degradation. If lakes develop on top of the sediments above the buried ice, and if the water does not freeze down to the bottom during winter, the temperature of the water favours rapid melting of the ice bodies, which, in turn, speeds up the degradation of the permafrost in the direct vicinity.

On the other hand, where the surface relief favoured constant drainage, buried ice could be preserved long, even till the Preboreal. This happened particularly with depressions close to a stream that incised the sedimentary cover during the Late Glacial (Błaszkiewicz, 2005), thus also with the oriented kettle holes in the outwash plain near Starogard Gdański. 


\section{Periglacial changes of soils}

More evidence for the presence of permafrost after the ice retreated from the study area consists of a layer in the uppermost sediments of the proximal part of the high outwash plain level near Stara Kiszewa, which is associated with the maximum extent of the ice during the Pomeranian phase. This outwash plain forms the highest proglacial outflow surface in this area near Wygonin (Błaszkiewicz, 1998) (Fig. 3). It results from stagnation of the ice front, while sediment supply by meltwater continued. Based on drillings in the proximal part of this high outwash plain, sandy boulder-containing gravel units with thicknesses of up to $10 \mathrm{~m}$ were found to dominate the upper part of the plain. From the line of the maximum ice extent towards the South, the gravel and boulder fractions systematically decrease in importance. The surface of the high outwash plain shows distinct signs of wind erosion with numerous occasionally extremely well developed - ventifacts.

The imprints left by a long-lived permafrost, reflecting periglacial conditions (cf. Vandenberghe \& Thorn, 2002), on soils were investigated by digging some holes through soil profiles in the study area. The artificial exposures were made in the marginal zone of the outwash plain, which is nowadays overgrown with a forest of Scots pines. The contemporary soil cover is a poorly developed podzol, which rests upon the rusty palaeosol that had formed under the periglacial conditions that developed after the deglaciation had started and that went on until the beginning of the Holocene.

Following the pedological concept that the soil formation in postglacial areas started under conditions of an Arctic tundra (Kopp, 1965, 1970; Catt, 1988; Blume et al., 1998; Degórski, 2007), it is likely that the morphogenetic and soil-forming processes in the study area continued for some 15,000 years. The degree to which the sediments became affected by these processes differs, however, from place to place, depending on when precisely a site became deglaciated, because this moment determined the duration of the periglacial processes, and in particular, the cryogenic weathering under permafrost conditions. The cryogenic conditions favoured changes in the soil profiles that depended on the levels' depth under the sedimentary surface. The properties of the soil thus became different with depth. This is consistent with numerous observations in other parts of central and northern Europe (Kopp, 1965, 1970; Kowalkowski, 1984, 1995; Degórski, 2007; Blume et al., 1998; Vandenberghe, 2001).

One of the analysed soil profiles (Fig. 6) shows a well developed sequence of frost-related changes, which result in characteristics that commonly are due to a variety of processes (cf. Kopp, 1969). Following the terminology of Kopp (1965, 1969), the profile can be described as follows. The surface layer consists of Holocene washed-out slope deposits, and has a thickness of about 10-15 cm (á). Then follows a periglacial zone $(\delta)$ with a thickness of approx. $80 \mathrm{~cm}$, followed by some

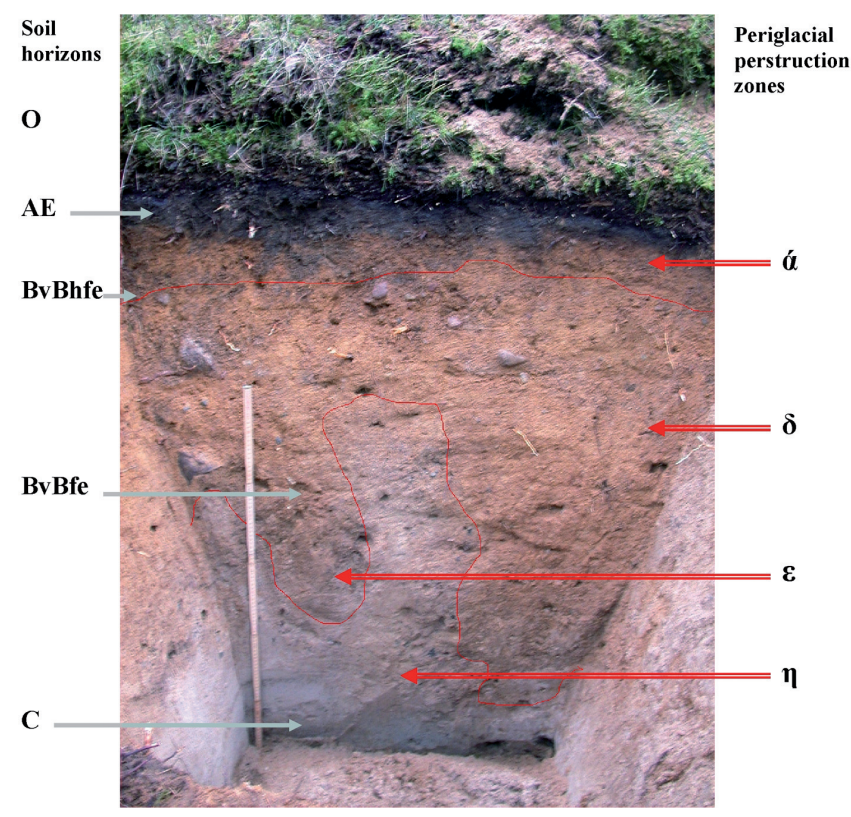

Fig. 6. Soil horizons and periglacially affected zones in an artificially dug profile.

$30 \mathrm{~cm}$ of a transitional zone $(\varepsilon)$ that rests directly on nonaffected sediments $(\eta)$.

The Holocene material, covering the older Pleistocene sediments, most probably results from both washing away and accumulation of fluvioglacial material from the edge of the outwash plain. There are also signs of wind activity (for instance in the form of ventifacts), which indicates subaerial weathering conditions. Under this layer, a well developed transitional periglacial zone occurs, which shows several characteristics that are typical of such a zone:

1. a significant thickness (roughly $80 \mathrm{~cm}$ );

2. disappearance of the layered structure, resulting from the seasonal disturbance of the material in the active layer of the permafrost (the re-icing zone);

3. a yellow-brown colour, due to humus-ferruginous coating of the grains in the periglacial environment;

4. a two times higher percentage of clay and silt than in the underlying material, as a result of frost-induced breakage of grains;

5. the appearance of numerous stones, resulting in enrichment of the gravel fraction.

The morphological traces of the frost-related weathering in the profile result from the cryogenic processes that took place, in combination with biological activity on the subarctic tundra. Some soil scientists consider these processes as true soilforming processes, as they give rise to the subarctic rusty soils with their characteristic Bv level (Kowalkowski, 1984). Such a soil will commonly become further developed and affected by subsequent pedogenic phases until a definite soil has been formed that is in balance with the climatic conditions and the vegetation. 
The soil under study here contains mor-type humus. The organic horizon is about $14 \mathrm{~cm}$ thick and its structure is as follows (Fig. 6): a litter subhorizon (0l) of $3 \mathrm{~cm}$, a fermentation subhorizon (0f) of $10 \mathrm{~cm}$, and an epi-humus subhorizon (0h) of 0.5-1 cm. The mineral part of the soil consists of: a humuseluvial horizon (AE) of 7-10 cm thick, an illuvial ferruginoushumus horizon (BvBhfe) of approx. 18-20 cm, and an illuvial ferruginous horizon (BvBfe), of roughly $55 \mathrm{~cm}$, passing gradually into the parent rock.

The surface of the high outwash soil horizon (AE) has been exposed for a relatively long time to periglacial conditions. This is, in addition to the above-mentioned periglacial indicator phenomena, demonstrated by the traces left by the active layer of the permafrost in the form of the guirlande-like cryoturbations visible in Fig. 6, as well as by the numerous ventifacts on the surface of the high outwash soil horizon (AE). Moreover, the long-term conservation of depressions with blocks of buried ice is a strong argument for the persistence of permafrost.

\section{Discussion}

Geomorphological studies concerning the Late Glacial area of Poland have resulted in a model that assumes a gradual appearance of permafrost in areas from which the continental glacier had retreated. A similar model is also commonly accepted in Germany (Liedtke, 1993; Böse, 1995). It is assumed in this model that the permafrost underneath the continental glacier - that had developed in front of the glacier when it advanced had almost completely disappeared. Recent studies in various areas, particularly those that were covered by the Laurentide ice sheet in North America, indicate, however, that the permafrost under the continental glacier did not disappear completely, and that degradation of the subglacial permafrost was limited to rather narrow zones under and alongside subglacial streams or lakes (French \& Harry, 1990; Clayton et al., 2001; Lacelle et al., 2004). A similar situation has recently been suggested for the Late Glacial areas of Poland, considering the essential role of subglacial permafrost in the development of subglacial drainage and the emergence of subglacial channels (Piotrowski et al., 2009).

In this context, it is interesting that recently (Szewczyk \& Nawrocki, 2011) permafrost was discovered at a depth of $357 \mathrm{~m}$ in a drill hole near Szypliszki (NE Poland). The site of the borehole was covered by ice during the last glaciation; the great depth of this permafrost makes it likely that it had developed in front of the advancing glacier rather than during retreat. It might even be a relict from an earlier glaciation. Whether this permafrost formed during the advance of the last ice cover or during an earlier glaciation, its present-day presence at such depth is definite proof that this permafrost has survived the coverage by a land-ice mass. One might, however, wonder whether the permafrost-related phenomena described here, including the deformation of the soil at Kara Kiszowa, might also - at least partly - be ascribed to deep seasonal frost at the end of the Late Vistulian rather than to true permafrost conditions. These questions have been raised before, and they have been answered by Kozarski (1975), who could prove that both the orientation of kettle holes and the soil deformations described here are, beyond any reasonable doubt, directly related to permafrost and not to seasonal temporary lows in temperature. We found no field evidence that is inconsistent with his findings.

Moreover, the deformations in the soil at Kara Kiszewa occur in a unit that was formed during the ice retreat of the Pommeranian phase; they thus cannot be due to pre-Pommeranian cold conditions. The soil development and the structures, including congelifraction, cannot be explained as a result of a short timespan with alternations of season-related freezing and thawing; only longer-lived permafrost conditions can explain these features satisfactorily.

\section{Conclusions}

The Late Glacial areas in northern Poland show a clear relationship between the successive stages of the retreat of the land-ice cap and the degree to which periglacial conditions could develop. The permafrost-related changes of the relief are least clear in the areas that were the last to become deglaciated (cf. Liedtke, 1993). It is commonly assumed that a permafrost extended over most parts of Poland; a discontinuous presence is assumed only for the area north of the maximum extent of the Pomeranian ice sheet.

Evidence for the presence of periglacial conditions and related soft-sediment deformations is found in the soil profiles of the Late Glacial areas (cf. Bukowska-Jania, 2003). These soils show zones with clear signs of periglacial features as defined and described by Kopp (1969), such as concentrations of clay/ silt fractions with minor amounts of fine sand that are twice as high as at other places, which results from congelifraction and other periglacial processes.

The present study also unambiguously proves the gradual appearance of the permafrost after deglaciation (but some 'fossil' permafrost that had developed in front of the advancing ice mass may have survived the burial under the ice, and thus have formed some kind of 'nucleus' for the ice of the permafrost that developed after the retreat of the land-ice mass). The traces of periglacially-induced features, both immediately in front of the ice and farther away, include deformations such as thermal contraction cracks, and morphological re-shaping of the area in the form of development of numerous oriented kettle holes in the outwash plains. The oriented depressions constitute not only important, morphological evidence of permafrost, but their partly biogenic infilling (cf. Litt et al., 2001) provides also much valuable information on its eventual degradation; they indicate, for instance, the persistence of the permafrost in northern Poland until the Preboreal (see also Błaszkiewicz, 2011). 
The deep (at least $100 \mathrm{~m}$ ) development of a long-lived permafrost, as demonstrated by the presence of buried ice in deep subglacial channels (Bukowska-Jania, 2003; Błaszkiewicz, 2005), and the long conservation (sometimes for even 5000 years) of buried dead-ice blocks leads to the conclusion that, after the ice of the Pomeranian phase of the Vistulian (Weichselian) glaciation had retreated, relicts of permafrost that had already developed in front of the advancing ice were still present when new permafrost developed in front of the retreating ice.

Finally, the study indicates that ice blocks that became buried under permafrost conditions, have played a major role regarding the morphogenesis of the Late Glacial areas of northern Poland. The degradation rate of the permafrost depended not only on the climatic amelioration, but to a large extent also on local conditions and in particular on the local hydrogeology.

\section{Acknowledgements}

This study is a contribution to the Virtual Institute of Integrated Climate and Landscape Evolution (ICLEA) of the Helmholtz Association.

\section{References}

Błaszkiewicz, M., 1998. Dolina Wierzycy, jej geneza oraz rozwój w późnym plejstocenie i wczesnym holocenie. (The Wierzyca Valley, its genesis and development in late Pleistocene and early Holocene). Dokumentacja Geograficzna 10.

Błaszkiewicz, M., 2005. Późnoglacjalna i wczesnoholoceńska ewolucja obniżeń jeziornych na Pojezierzu Kociewskim (wschodnia część Pomorza). (Late Glacial and early Holocene evolution of the lake basins in the Kociewskie Lakeland - eastern part of the Pomeranian Lakeland). Prace Geograficzne 201: 1-192.

Błaszkiewicz, M., 2011. Timing of the final disappearance of permafrost in the central European Lowland, as reconstructed from the evolution of lakes in $\mathrm{N}$ Poland. Geological Quarterly 55: 361-374.

Blume H., Beyer, L. \& Schneider D., 1998. Soils of the southern circumpolar region and their classification. Eurasian Soil Science 31: 477-485.

Böse, M., 1995. Problems of dead ice and ground ice in the central part of the North European Plain. Quaternary International 28: 123-125.

Boulton, G.S., 1967. The development of a complex supraglacial moraine at the margin of Sørbreen, Ny Friesland, Vestspitsbergen glaciers. Journal of Glaciology 6: 717-736.

Brodzikowski, K. \& Van Loon, A.J., 1991. Glacigenic sediments. Developments in Sedimentology 49, Elsevier (Amsterdam), 674 pp.

Bukowska-Jania, E., 2003. Rola systemu lodowcowego w obiegu węglanu wapnia w środowisku przyrodniczym (na przykładzie Svalbardu i młodoglacjalnych obszarów Polski północno-zachodniej (The role of glacier systems in the migration of calcium carbonate in the natural environment with particular reference to Svalbard and the last-glacial areas in NW Poland). Silesian University Press, Katowice, 247 pp.
Catt, J., 1988. Quaternary geology for scientists and engineers. John Wiley and Sons, New York, $335 \mathrm{pp}$.

Cegła, J. \& Kozarski, S., 1977. Sedimentary and geomorphological consequences of the occurrence of naled sheets on the outwash plain of the Gaas Glacier, Soerkappland, Spitsbergen. In: Results of investigations of the Polish scientific Spitsbergen expeditions 1970-1974, 2. Acta Universitatis Wratislaviensis 387: 63-84.

Clayton, L., Attig, J.W. \& Mickelson, D.M., 2001. Effects of Late Pleistocene permafrost on the landscape of Wisconsin, USA. Boreas 30: 173-188.

Degórski, M., 2007. Spatial variability in podzolic soils of central and northern Europe. U.S. Environmental Protection Agency Report, 178 pp.

Ewertowski, M., 2009. Ice-wedge pseudomorphs and frost-cracking structures in Weichselian sediments, central-west Poland. Permafrost and Periglacial Processes 20: 316-330.

Florin, M. \& Wright Jr, H.E., 1969. Diatom evidence for the persistence of stagnant glacial ice in Minnesota. Geological Society of America Bulletin 80: 694-704.

French, H.M. \& Harry, D.G., 1990. Observations on buried glacier ice and massive segregated ice, western Arctic coast, Canada. Permafrost and Periglacial Processes 1: 31-43.

Gedl, P., 2011. Palynology of Late Pleistocene varved clays from ice-dammed lakes at Lebork and Zlocieniec (north-western Poland). Geologos 17: 49-59.

Hambrey, M.J., 1984. Sudden draining of ice-dammed lakes in Spitsbergen. Polar Record 22: 189-194.

Klatkowa, H., 1994. Evaluation du rôle de l'agent periglaciaire en Pologne centrale. Biuletyn Peryglacjalny $33:$ 79-100.

Kopp, D., 1965. Die periglaziäre Deckzone (Geschiebedecksand) im nordostdeutschen Tiefland und ihre bodenkundliche Bedeutung. Berichte der Geologischen Gesellschaft in der DDR 10: 739-771.

Kopp, D., 1969. Die Waldstandorte des Tieflandes - Ergebnisse der forstlichen Standortserkundung in der Deutschen Demokratischen Republik. VEB Forstprojektierung, Potsdam: 9-141.

Kopp, D., 1970. Kryogene Perstruktion und ihre Beziehung zur Bodenbildung im Moränengebiet In: H. Richter, G. Haase, I. Lieberoth \& R. Ruske (eds): Periglazial. Löss - Paläolithikum im Jungpleistozän der DDR. Petermanns Geografische Mittteilungen und Ergebnisse 274: 269-279.

Kowalkowski, A., 1984. Surface texture of quartz grains from tundra soils under electron microscope. Quaternary Studies in Poland 5: 75-80.

Kowalkowski, A., 1990. Evolution in Holocene soils in Poland. Quaestiones Geographicae, Special Issue 4: 93-120.

Kowalkowski, A., 1995. Catena of podzolic soils on the northern slope of Västerskutan in the massif of the Åreskutan, Jämland. Quaestiones Geographicae, Special Issue 4: 185-193.

Kozarski, S., 1975. Oriented kettle holes in outwash plains. Quaestiones Geographicae 2: 99-112.

Kozarski, S., 1993. Late Plenivistulian deglaciation and the expansion of the periglacial zone in NW Poland. Geologie en Mijnbouw 72: 143-157.

Krüger, J. \& Kjaer, K.H., 2000. De-icing progression of ice-cored moraines in a humid, subpolar climate, Kötlujökull, Iceland. The Holocene 10: 737-747.

Lacelle, D., Bjornson, J., Lauriol, B., Clark, I.D. \& Troutet, Y., 2004. Segregatedintrusive ice of subglacial meltwater origin in retrogressive thaw-flow headwalls, Richardson Mountains, NWT, Canada. Quaternary Science Reviews 23: 681-696. 
Last, W.M. \& Vance, R.E., 2002. The Holocene history of Oro Lake, one of western Canada's longest continuous lacustrine records. Sedimentary Geology 148: 161-184.

Liedtke, H., 1993. Phasen periglaziär-geomorphologischer Prägung während der Weichseleiszeit im norddeutschen Tiefland. Zeitschrift für Geomorphologie 93: 69-94.

Litt, Th., Brauer, A., Goslar, T., Merkt, J., Balaga, K., Müller, H., RalskaJasiewiczowa, M., Stebrich, M. \& Negendank, J.F.W., 2001. Correlation and synchronisation of Lateglacial continental sequences in northern central Europe based on annually laminated lacustrine sediments. Quaternary Science Reviews 20: 1233-1249.

Marks, L., 2002. Last Glacial Maximum in Poland. Quaternary Science Reviews 21: 103-110.

Marks, L., Ber, A., Gogołek, W. \& Piotrowska, K. (eds), 2006. Geological map of Poland 1:500 000 with explanatory text. Państwowy Instytut Geologiczny, Warszawa.

Morawski, W., 2009a. Neotectonics induced by ice-sheet advances in NE Poland. Geologos 15: 199-217.

Morawski, W., 2009b. Differences in the regional stratigraphy of NE Poland caused by vertical movements due to glacioisostasy. Geologos 15: 235-250.

Niewiarowski, W., 2003. Pleni- and late Vistulian glacial lakes, their sediments and landforms: a case study from the young glacial landscape of northern Poland. In: A. Kotarba (ed.): Holocene and late Vistulian paleogeography and paleohydrology. Prace Geograficzne 189: 61-85.

Nitz, B., 1984. Grundzüge der Beckenentwicklung im mitteleuropäischen Tiefland Modell einer Sediment- und Reliefgenese. Petermanns Geographische Mitteilungen 128: 133-141.

Piotrowski, J.A., Hermanowski P. \& Piechota, A.M., 2009. Meltwater discharge through the subglacial bed and its land-forming consequences from numerical experiments in the Polish lowland during the last glaciation. Earth Surface Processes and Landforms 34: 481-492.

Pisarska-Jamroży, M. \& Börner, A., 2011. Is the Charlottenthal fan (marginal zone of the Pomeranian phase, NE Germany) an end moraine? Geologos 17: 17-28.

Rachlewicz, G., 1991. Morfogeneza stożka sandrowego w strefie marginalnej fazy pomorskiej koło Kołtek w świetle badań osadów powierzchniowych (Morphogenesis of a sandur cone in the marginal zone of the Pommeranian phase near Koltki based on analysis of the surficial deposits). Badania Fizjograficzne Polski Zachodniej 42, Seria A Geografia Fizyczna, Poznań: 205-228.

Schomacker, A., 2008. What controls dead-ice melting under different climate conditions? A discussion. Earth-Science Reviews 90: 103-113.

Schwalb, A. \& Dean, W.E., 2002. Reconstruction of hydrological changes and response to effective moisture variations from North-Central USA lake sediments. Quaternary Science Reviews 21: 1541-1554.

Szewczyk, J. \& Nawrocki, J., 2011. Deep-seated relict permafrost in northeastern Poland. Boreas 40: 385-388.

Vandenberghe, J., 2001. Permafrost during the Pleistocene in northwest and central Europe. In: Paepe, R. \& Melnikov, V. (eds): Permafrost response on economic development, environmental security and natural resources. Kluwer Academic Publishers, Dordrecht: 185-194.

Vandenberghe, J., 2002. The relation between climate and river processes, landforms and deposits during the Quaternary. Quaternary International 91: 17-23.
Vandenberghe, J., 2006. Cryoturbation structures. In: Elias, S.A. (ed.): Encyclopedia of Quaternary Science. Elsevier, Amsterdam: 2147-2153.

Vandenberghe, J. \& Czudek, T., 2008 Pleistocene cryopediments on variable terrain. Permafrost and Periglacial Processes 19: 71-83.

Vandenberghe, J. \& Kasse, C., 1993a. Periodic ice-wedge formation and Weichselian cold-climate floodplain sedimentation in the Netherlands. Proceedings $6^{\text {th }}$ International Conference on Permafrost (Beijing) 1: 643-647.

Vandenberghe, J. \& Kasse, C., 1993b. Cryopedimentation on soft-sediment subsoils. Würzburger Geographische Arbeiten 87: 283-297.

Vandenberghe, J. \& Thorn, C.E., 2002 Progress in periglacial research. Progress in Physical Geography 26: 475-477.

Vandenberghe, J., Cui, Z.J., Zhao, L. \& Zhang, W., 2004. Thermal contraction crack networks as evidence for Late-Pleistocene permafrost in Inner Mongolia. Permafrost and Periglacial Processes 15: 21-29.

Van Huissteden, J., Vandenberghe, J., Van der Hammen, T. \& Laan, W., 2000. Fluvial and aeolian interaction under permafrost conditions: Weichselian Late Pleniglacial, Twente, eastern Netherlands. Catena 40: 307-321.

Van Loon, A.J., 2009. Soft-sediment deformation structures in siliciclastic sediments: an overview. Geologos 15: 3-55.

Więckowski, K., 1966. Osady denne Jeziora Mikołajskiego (Bottom deposits of Lake Mikołajki). Prace Geograficzne 57, 112 pp. 